\title{
Research on the Operation Mechanism of High Vocational Colleges and Enterprises Cooperation under the Background of Integration of Production and Education
}

\author{
Chen $\mathrm{Lu}$ \\ School of Information Engineering \\ Suzhou Industrial Park Institute of Service Outsourcing \\ Suzhou, China \\ luc@siso.edu.cn
}

\author{
Zheng Liu \\ School of Information Engineering \\ Suzhou Industrial Park Institute of Service Outsourcing \\ Suzhou, China \\ liuz@siso.edu.cn
}

\author{
Jianfeng Jiang \\ School of Information Engineering \\ Suzhou Industrial Park Institute of Service Outsourcing \\ Suzhou, China \\ jiang.jf@siso.edu.cn
}

\begin{abstract}
Based on the situation that the high vocation Colleges are a one-way relationship with enterprises about cooperating between them, and combined with the trend of economic development in current region, we are researching the operation mechanism of school-enterprise cooperation under the deep integration of production and education, as an example of IT outsourcing industry, which includes the main research contents: the classifying management mechanism of cooperative types, the dynamic adjustment mechanism of talent cultivation plans, the immediate response mechanism of employment demand, exchange visit mechanism of teachers and employees based on projects, exchange evaluation and selection mechanism of cooperative object. According to these mechanisms, we can cooperate between higher vocational colleges and enterprises effectively, cultivate more qualified talents, and help enterprises choose more suitable employees, which is win-win cooperation for both sides.
\end{abstract}

Keywords-Integration of Production and Education, School-Enterprise Cooperation, Operation Mechanism, High Vocation College

\section{INTRODUCTION}

In 2015, the Ministry of Education issued "Several Opinions on Deepening the Reform in Vocational Education and Teaching and Raising the Quality of Talents in an All-Round Way." The Opinions set out the guiding ideology and basic principles for deepening the reform in teaching of vocational education and improving the quality of personnel training in an all-round way. It explicitly put forward that taking perfect people as the foundation, taking service development as its goal, promoting employment as its orientation, and sticking to the connotative development path,

2016 Jiangsu Provincial Education Science "13th Five-Year Plan" Special Youth Research Project named” Research on the Guarantee Mechanism of Higher Vocational Schools and Enterprises under the Integration of Production and Teaching - Taking IT Outsourcing Industry as an Example”, C-c/2016/03/38
To adapt to the new normal of economic development and to develop talents for technical skills and talents, to perfect the system of integration of production and teaching, to coordinate the mechanism of educating students and to cultivate innovative personnel [1].

Based on the situation that the high vocation Colleges are a one-way relationship with enterprises about cooperating between them, and combined with the regional economic development trend of IT industry in southern Jiangsu, especially Suzhou Industrial Park and the orientation and mode of our College, the paper is mainly to investigate the main cooperation forms, cooperation achievements, emerging problems and difficulties in the process of cooperation between schools and enterprises, to study the establishment of operating mechanism of depth integration of school-enterprise cooperation about deeply integration of schools and enterprises to stimulate enterprises to participate in the professional construction and personnel training, to promote mutual benefits and win-win for both schools and enterprises of production and education. Thus, it will bring vocational school vitality, delivery of qualified personnel for the enterprise.

\section{RESEARCH STATUS AT HOME AND ABROAD}

At present, there are two major types of school-enterprise cooperation in the world. One is the enterprise-based school-enterprise cooperative education model, which is represented by Germany's "Dual System", the British "Sandwich Work-Study system" and Japan's "Production-School Cooperation system". The second is a school-based school-enterprise cooperative education model. Representatives are the "Cooperative Education" in the United States, "The two-track System" in Singapore and the 
"School-Base Enterprise System” in Russia. Combined with their own industrial needs, these developed countries introduce a large number of policies and laws to encourage enterprises to participate in vocational education, and directly participate in the whole process of running a vocational education, which make the school-enterprise cooperation closed, interdependently, development together, and cooperation perfectly [2].

In recent years, the development of domestic vocational education has taken a new step. The State Council held three meetings of the national work conference on vocational education successively and made two decisions on vigorously developing vocational education in 2002 and 2005. It clearly defined vocational education as an important foundation for our economic and social development and a strategic focus of education. The policy environment, public opinion environment and social environment for education development have been significantly improved. And clearly defined three major tasks of vocational education: consolidation, development and improvement. At this point, China's vocational education has entered a golden stage of development. In 2011, in order to thoroughly implement the spirit of the important speech made by General Secretary Hu Jintao at the General Assembly celebrating the 100th anniversary of the founding of Tsinghua University and the "Outline of the National Medium and Long-term Education Reform and Development Plan (2010-2020)", promote institutional innovation and deepen the reform of institutional mechanisms Enterprises and schools to further promote the development of higher vocational schools. MOE released Circular 12: Several Opinions of the Ministry of Education on Promoting the Reform and Innovation of Higher Vocational Education and Leading the Scientific Development of Vocational Education. In 2014, the State Council released Circular No. 19 "Decision of the State Council on Accelerating the Development of Modern Vocational Education", clearly pointing out that accelerating the development of modern vocational education [3]. In 2015, the Ministry of Education issued "Several Opinions on Deepening the Reform in Teaching Reform of Vocational Education to Improve the Quality of Talents in an All-Round Way", which clearly defined the guiding ideology and basic principles for deepening the reform of vocational education and teaching and improving the overall quality of personnel training.

In many years of reform practice, many schools and enterprises across the country have carried out cooperation with schools and enterprises in different forms and at different levels, and at the same time; they have also set a typical example of cooperation between schools and enterprises. "Orders," "leading enterprises to enter schools", "school in the factory, the school of central", "school league", "occupation education group" and other schools, enterprises, government-led school-enterprise cooperation, strengthen professional and industry docking, Highlighting the achievements of school-enterprise cooperation, a large number of solutions worth learning from came into being. For example, the establishment of "enterprise university" by the school's second-level college or department and the enterprise to enable the enterprise to truly participate in the daily teaching of the school. The Ministry of Education's high education department-led co-educational project of production, teaching and education encourages enterprises to come up with their own technical training, training equipment and other advanced resources, signed cooperation agreements with colleges and universities to help schools carry out teacher training, training room to build, student technical skills training and the introduction of curriculum resources[4].

\section{THE STUDY OF OPERATION MECHANISM}

\section{A. Analysis of the Current Situation of School - Enterprise Cooperation}

The essence of the enterprise is profit-seeking, qualified personnel can be recruited to be able to quickly carry out the project implementation, so that the interests of the company to maximize. The most important function of vocational colleges is to train qualified personnel for the industry. From the theoretical analysis, the two main bodies of school and enterprise can realize a win-win situation through the integration of industry and education and the cooperation between school and enterprises. However, the reality is that there is a fever in higher vocational colleges and a shortage of employing enterprises. Many enterprises are not enthusiastic about participating in the training of qualified personnel in higher vocational colleges. However, the progress in the cooperation between colleges and enterprises in higher vocational colleges is slow and the professional counterparts in internship and employment Not high rate.

After surveying and researching related enterprises and brother colleges and universities in southern Jiangsu province, the advantages and disadvantages are analyzed in terms of cooperation methods, training programs, student skills, teacher teams and evaluation and assessment, as shown in Fig. 1. 


\begin{tabular}{|c|c|c|c|}
\hline \multirow{3}{*}{$\begin{array}{l}\text { Cooperation } \\
\text { Types }\end{array}$} & \multicolumn{2}{|l|}{ High Vocational School } & Cooperation Enterprise \\
\hline & \multicolumn{2}{|c|}{$\begin{array}{l}\text { willing to use a variety of coop eration between school } \\
\text { and enterprise }\end{array}$} & $\begin{array}{r}\text { Can not participate in all aspects of school- } \\
\text { enterprise cooperation }\end{array}$ \\
\hline & $\begin{array}{l}\text { more cooperation enterprise but no more } \\
\text { efficiency }\end{array}$ & & $\begin{array}{r}\text { Clear positioning of en terprises } \\
\text { with executive power }\end{array}$ \\
\hline \multirow{2}{*}{$\begin{array}{l}\text { Training } \\
\text { Program }\end{array}$} & \multicolumn{2}{|c|}{$\begin{array}{l}\text { More perfect theor etical teaching and moral ed ucation } \\
\text { system }\end{array}$} & Less time for staff technical skills training \\
\hline & $\begin{array}{l}\text { Inability to keep abreast of the demand for } \\
\text { qualified personnel }\end{array}$ & \multicolumn{2}{|c|}{$\begin{array}{r}\text { Clear demand for qualified personnel, and have strict } \\
\text { requirem ents of the skills required }\end{array}$} \\
\hline \multirow{2}{*}{$\begin{array}{l}\text { Students } \\
\text { Skills }\end{array}$} & \multicolumn{2}{|c|}{$\begin{array}{l}\text { Student resources are rich, and have a large number of } \\
\text { personn el training time }\end{array}$} & $\begin{array}{r}\text { Talent demand slow response, high } \\
\text { recruitment costs }\end{array}$ \\
\hline & $\begin{array}{l}\text { Lack of suitable, enough real project to } \\
\text { exercise }\end{array}$ & \multicolumn{2}{|c|}{ A large numb er of real projects, rich project resources } \\
\hline \multirow{2}{*}{$\begin{array}{l}\text { Teacher } \\
\text { Group }\end{array}$} & \multicolumn{2}{|l|}{ Rich teaching experience } & Lack of teaching experience \\
\hline & $\begin{array}{l}\text { Lack of practical ability, cannot keep up with } \\
\text { the most advanced technology }\end{array}$ & \multicolumn{2}{|c|}{ Employees have strong practical ability and experience } \\
\hline \multirow{2}{*}{$\begin{array}{l}\text { Assessment } \\
\text { System }\end{array}$} & \multicolumn{2}{|c|}{$\begin{array}{l}\text { more perfect school-enterprise cooperation assessm ent } \\
\text { system }\end{array}$} & $\begin{array}{r}\text { Lack of evaluation standards with } \\
\text { schools }\end{array}$ \\
\hline & $\begin{array}{l}\text { Focus on quantitative data, lack of classification } \\
\text { and detailed assessment indicators }\end{array}$ & Focus on the & $\begin{array}{l}\text { tiveness of coop eration, and bring } \\
\text { icant ben efits through cooperation }\end{array}$ \\
\hline
\end{tabular}

Fig. 1. The Advantages and Disadvantages between Enterprises and Schools

\section{B. Design of Operation Mechanism of School-Enterprise Cooperation}

According to the investigation and analysis of the status quo of the cooperation between schools and enterprises, the strengths and weaknesses of both schools and enterprises are complementary. Aiming at this phenomenon, this paper puts forward a set of cooperation mechanism of school-enterprise cooperation under the background of product-teaching integration. The main contents include: classification management mechanism of cooperation pattern, dynamic adjustment mechanism of personnel training specification, immediate response mechanism of talent demand, Exchange of visits mechanism, cooperation between mutual selection of peer evaluation mechanism and other effective measures to protect the vocational colleges and universities to effectively carry out cooperation between schools and schools to train more qualified personnel, enterprises selected more suitable staff, both school and enterprise mutual benefit and win-win (Fig. 2).

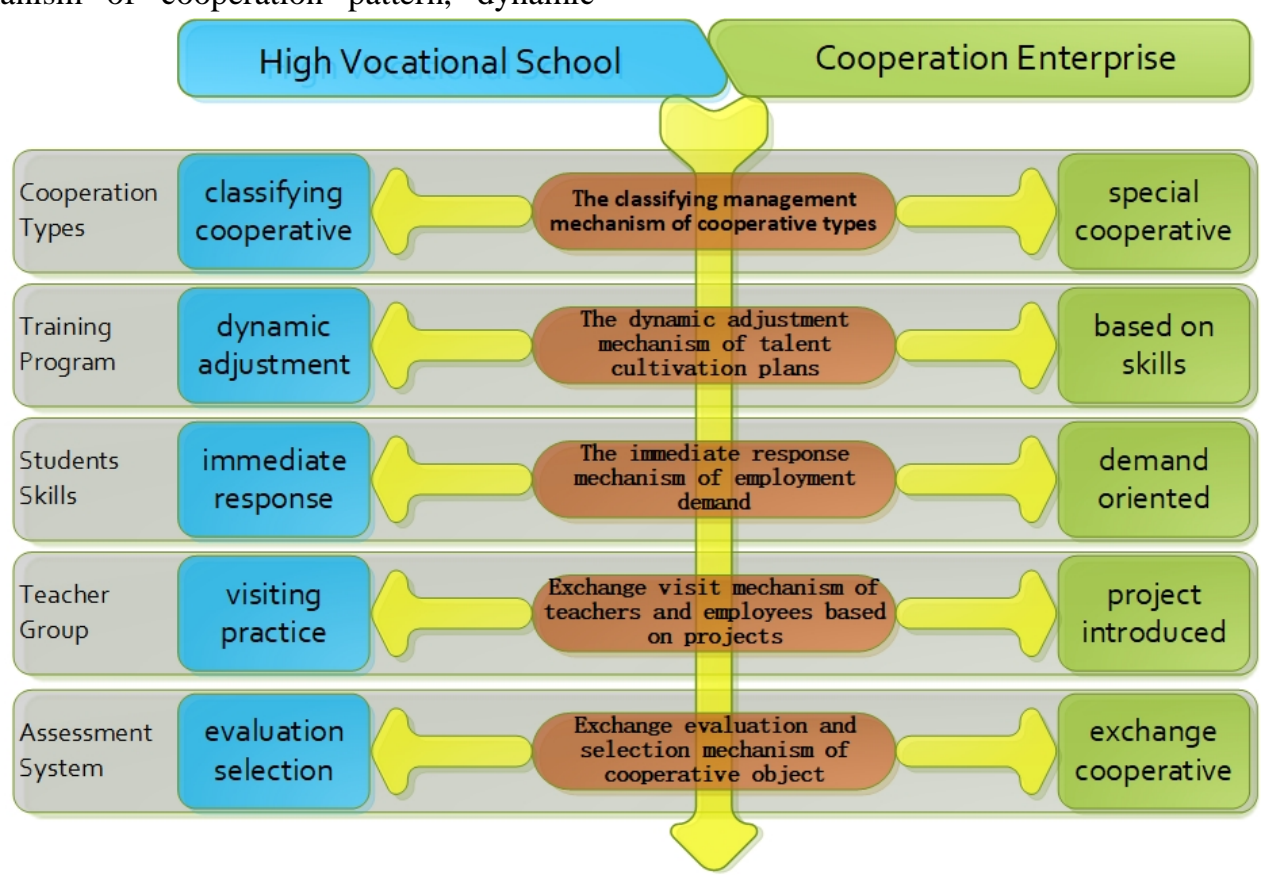

Fig. 2. The Operation Mechanism of School-Enterprise 
- The classifying management mechanism of cooperative types: constructing School-enterprise cooperation model

According to the type and size of enterprises, IT professional characteristics, we need to develop a different school-enterprise cooperation model, such as for industry-led enterprises, we need these leading enterprises as the basis, to carry out professional co-construction, training base Co-construction and other cooperation; if enterprises mainly engaged in internships to carry out cooperation, you can set up internship training base. Through the establishment of a reasonable corporate classification and cooperation, classification management mechanism, can achieve the maximum extent of school-enterprise cooperation; give full play to the advantages and capabilities of enterprises.

- The dynamic adjustment mechanism of talent cultivation plans: adjust the talent cultivation plans

Through the establishment of enterprise demand statements for the next three years, every six months to update the needs of business personnel needs, such as knowledge and skills needs, job skills needs, professional literacy needs, timely adjustment of various professional school training programs in the consolidation of freshman professional knowledge base Under the premise of skills teaching, the sophomore and junior semester dynamic adjustment of the curriculum and teaching content, so that the training of professionals can adapt to most counterparts of talent demand specifications.

- The immediate response mechanism of employment demand: establish the database of students' skill information

Through the research found that the employment needs of enterprises with irregular, short-term, companies will be based on their own development and project needs in a relatively short period of time to recruit the right talent, technical skills requirements will appear immediately, the company in the process of hiring employees Often appear needy people can't arrive on time. College student resources have become one of the main ways to supplement the employment needs of enterprises. By establishing a database of students' technical skills and grasping the passing rate of students for each stage of learning, we quickly select students who are in line with the urgent need of enterprises for selection by employers in line with the flexible credit system that our school is implementing. Students who meet the requirements You can enter the enterprise to participate in the implementation of real projects to solve the urgent needs of enterprises, the project is completed, students can return to school to continue their studies, you can continue to exercise in the business, the real practice of "work-study alternant, internship."

- Exchange visit mechanism of teachers and employees based on projects: establish teacher group

The cultivation of students is inseparable from the development of college teachers themselves, but only rely on college teachers can't meet the requirements of enterprises. Through the establishment of school-enterprise staff project-based exchange of visits to the project as a carrier, colleges and universities in the process of project teaching if the need for short-term project practice teaching (case teaching, semester projects), you can ask business engineers as part-time teachers into the classroom simulation business Real projects in the scene teaching; enterprises in the implementation of project development, if there is a shortage of talent, the progress of the situation, you can hire our hospital professional teachers involved in project development, the college to develop policies to encourage teachers to actively participate in the implementation of enterprise projects. In addition, the school regularly invites business engineers to our faculty and students to carry out the latest technology lectures, companies can also hire our teachers to new staff for professional skills training.

- Exchange evaluation and selection mechanism of cooperative object: establish the evaluation of school-enterprise

With the rapid development of information technology, enterprises will adjust their talent needs according to their own development. Colleges and universities will also adjust personnel training specifications according to their professional development. Through the establishment of a mechanism for the selection of cooperative enterprises, the various specializations of colleges and universities evaluate regularly according to the cooperation effectiveness of cooperative enterprises, eliminate some enterprises that have little success in cooperation and have low rates of cooperation, and timely absorb new enterprises with good prospects for development and strong cooperation; at the same time, enterprises can According to their own development status, strengthen the depth of cooperation with the school or cancel the cooperation. Through this reciprocal evaluation mechanism, schools can maintain the vitality of school-enterprise cooperation and enterprises can timely adjust the contents of school-enterprise cooperation so that both school-enterprise cooperation can concentrate on strengthening school-enterprise cooperation.

\section{CONCLUSION}

Through the above series of mechanisms, we will focus on solving the problems that may arise during the integration of industry and education directly between higher vocational colleges and enterprises and the cooperation between schools and enterprises, and resolving the school's different types of school-enterprise cooperation for different types of enterprises. Through the program of talent training Adjust the timely response to the technical and technical needs of enterprises; establish student skills files, targeted to recommend suitable talents for the enterprise, timely response and feedback to the enterprise's employment needs; professional teachers and enterprise engineers to carry out project-based mutual visits, one In the aspect of strengthening the practical ability of professional teachers, on the one hand, timely introduce the advanced technology of enterprises into the classroom to ensure the advanced nature of personnel training; finally, mutual evaluations are made between institutions and enterprises on a regular basis so as to timely adjust the cooperation strategy between schools and enterprises and carry out the integration of production and teaching efficiently. 


\section{REFERENCES}

[1] The Ministry of Education issued "Several Opinions on Deepening the Reform in Vocational Education and Teaching and Raising the Quality of Talents in an All-Round Way.",2015-08-17.

[2] J YE. Study on Guarantee Mechanism of Cooperation between School and Enterprise in Higher Vocational Education.J.Education and vocation ,vol.10. pp.30-32,2015.
[3] Decision of the State Council on Speeding up the Development of Modern Vocational Education,2014-05-29.

[4] Y ZHU. The Types and Operating Mechanism of School - Enterprise Cooperation in Higher Vocational Colleges J. Vocational and Technical Education,vol.35, pp.55-57, 2015. 